\title{
Raptor assemblages in grasslands of Southern Brazil: species richness and abundance and the influence of the survey method
}

\author{
Felipe Zilio ${ }^{1,5^{*}}$, Alan Bolzan ${ }^{2}$, André de Mendonça-Lima ${ }^{3}$, Cristiane Oliveira da Silva ${ }^{3}$, Laura Verrastro ${ }^{4,5}$ \\ and Márcio Borges-Martins ${ }^{4,5}$
}

\begin{abstract}
Background: Raptor distributions and abundances are poorly known in southern Brazil. Given that raptors have low population densities, methods typically applied to census birds are usually inappropriate for surveying raptors. Roadside surveys allow large areas to be searched at a relatively low cost and are often applied to count raptors. We conducted eight paired roadside surveys (roadside point transects and roadside strip transects of $54.5 \sim 58.6 \mathrm{~km}$ long) to assess the species richness and abundance of raptors in two grassland landscapes of southern Brazil and to compare results of the two methods.

Results: In total, 1,890 observations of 18 raptor species (118.13 individuals (ind.)/transect) were recorded. Raptor abundances were higher in the altitudinal grasslands (299.25 $\pm 48.91 \mathrm{ind}$./transect) than in the coastal plain (86.63 $\pm 44.04 \mathrm{ind}$./transect). Abundances were higher when raptors were surveyed with point transects (9.38 ind. $\cdot\left[10 \mathrm{~km}^{2}\right]^{-1} \cdot \mathrm{h}^{-1}$ ) than with strip transects $\left(3.55 \mathrm{ind} \cdot \cdot\left[10 \mathrm{~km}^{2}\right]^{-1} \cdot \mathrm{h}^{-1}\right.$ ). No significant differences were found in relation to species richness, although five species were exclusively recorded with point transects versus one with strip transects.

Conclusions: Roadside point transects may reduce bias due to differences in species detection caused by habitat features and in abundance estimates resulting from survey habitat being disproportional to their availability. Point counts may enhance the quality of the search for raptors in a surveyed area, increasing the detection probability. The choice of survey method depends on the objectives of the study, but our results favor the use of point transects rather than strip transects to survey raptors in open landscapes.
\end{abstract}

Keywords: Diurnal raptors; Open landscapes; Point transect; Roadside survey; Strip transect

\section{Background}

Brazil has 75 raptor species (CBRO 2011) that comprise $82 \%$ of those known for South America (Remsen et al. 2012). Few studies of raptors have been done in South America (Bierregaard 1995, 1998), and as a result, many species are poorly known. In recent years, studies were published describing nests and breeding biology (e.g., Zilio

\footnotetext{
* Correspondence: fzilio@msn.com

'Programa de pós-graduação em Biologia Animal, Departamento de Zoologia, Universidade Federal do Rio Grande do Sul, Av. Bento Gonçalves, 9500, Porto Alegre CEP 91501-970 Rio Grande do Sul, Brazil

${ }^{5}$ Laboratório de Herpetologia, Departamento de Zoologia, Universidade Federal do Rio Grande do Sul, Av. Bento Gonçalves, 9500, Porto Alegre CEP 91501-970 Rio Grande do Sul, Brazil

Full list of author information is available at the end of the article
}

and Mendonça-Lima 2012), diet (e.g., Scheibler 2007), taxonomy (e.g., Amaral et al. 2009), migration (e.g., Cabanne and Seipke 2005), and distribution (e.g., Mendonça-Lima et al. 2006; Meller and Bencke 2012), but much of the information comes from short-term studies or opportunistic observations. Data at the assemblage level (e.g., distributions, abundances, and habitat associations) are scarce and were usually collected in short-term studies (Azevedo et al. 2003; Mañosa et al. 2003; Loures-Ribeiro and Anjos 2006; Alencar-Carvalho and Marini 2007; Salvador-Jr and Silva 2009).

Although species occurrences and distributions in Rio Grande do Sul were well summarized in the work of Belton (1984) in the 1970s and through additional records 
(Krügel 2003; Albuquerque et al. 2006; Barcellos and Accordi 2006; Joenck 2006; Joenck and Azevedo 2006; Mendonça-Lima et al. 2006; Meller and Bencke 2012), data regarding abundances are scattered, being found primarily in general bird surveys. Exceptions are the works by Albuquerque et al. (1986) along the southern coast, the first systematic survey done in the state, Petersen et al. (2011) in the northeastern part of the state, Meller (2011) at Turvo State Park in the northwestern area, and Zilio et al. (2012) in southern Brazil and Uruguay. Given the relative scarcity of systematic surveys of raptors and their importance as indicators of habitat quality and biodiversity (Sergio et al. 2006, 2008), our goal was to describe the assemblages of raptors in two grassland landscapes in Rio Grande do Sul.

The study was conducted on the South Brazilian Plateau in the northeastern region of the state and on the coastal plain (Figure 1). Altitudinal grasslands cover $13,740 \mathrm{~km}^{2}$ of the South Brazilian Plateau, mostly in the Brazilian states of Rio Grande do Sul and Santa Catarina (Overbeck et al. 2007). This region is characterized by the highest elevations in southern Brazil (up to 1,800 m) in addition to a subtropical climate, with warm summers, cold winters (with the formation of frost), and the absence of a dry season. The grassland dominates the upper parts, on hilltops, forming mosaics with Araucaria forests, which are patchily distributed. Forest habitats prevail on hill and river slopes. Several regionally threatened bird species have only recently been recorded in this region (Bencke et al. 2003), which has three of the 14 important bird areas (IBAs) identified in Rio Grande do Sul (Bencke et al. 2006). The coastal plain is an extended $(620 \mathrm{~km})$ and wide (up to $100 \mathrm{~km}$ ) physiographic territory, covering $33,000 \mathrm{~km}^{2}$ of Rio Grande do Sul (Tomazelli et al. 2000). This large lowland contains numerous water bodies, some rather large, such as the Patos Lagoon, with an area of $10,000 \mathrm{~km}^{2}$ (Tomazelli et al. 2000). The climate of this region is subtropical and very wet, and it lacks a dry season. Grass vegetation types dominate the landscape with patches of forest remnants (gallery forests and palm savannahs). Lagoa do Peixe National Park, a RAMSAR site (http://www.ramsar.org), and three more IBAs (Bencke et al. 2006) are located along the coast of Rio Grande do Sul.

Roadside surveys are often applied to count raptors (see Andersen 2007 and references therein). Roads are features of most landscapes, and surveys conducted along them allow the exploration of large areas at a relatively low cost. Despite the bias associated with road surveys (e.g., Fuller and Mosher 1987; Millsap and LeFranc 1988; Austin et al. 2000), roadsides can be useful to describe assemblage compositions, species distributions and abundances, and habitat preferences (Fuller and Mosher 1987; Andersen 2007). Strip/line transects (surveying an area which includes both sides of a transect line, as the observer moves in a specific direction; Ralph 1981) and point transects (recording detections at static points along a sample trip at regular intervals) are the most common methods to survey raptors in open areas. Both are used to count birds and, in this context, have been the subject of debate and improvements (e.g., Ralph and Scott 1981; Rosenstock et al. 2002; Thompson 2002; Alldredge et al. 2008; Buckland et al. 2008). However, seeing that there is no study comparing how these techniques work when surveying raptors, we conducted paired roadside surveys to analyze the performance of each method in detecting raptor richness and abundance in open landscapes in southern Brazil. We hypothesized that roadside point transects would be better than strip/ line transects when surveying raptors in grasslands since fixed-point counts are better than transects when surveying forest raptors (Whitacre and Turley 1990).

\section{Methods}

\section{Raptor surveys}

Raptor assemblages were surveyed along four routes in July 2009 and March 2010 (Figure 1). Each route was surveyed using two methods (a roadside point transect and a roadside strip transect) totaling 16 raptor surveys (four paired surveys per month). Each paired survey was carried out on consecutive days, or with a week interval between them, under similar weather conditions (e.g., cloud cover and wind speed) to minimize bias in the probability of detection of raptors caused by abiotic characteristics (e.g., traffic and weather). Survey routes were placed on double-lane paved roads ( $c a .9 \mathrm{~m}$ wide, with traffic density at $c a$. 75 vehicles per hour; F Zilio personal observation). Surveys were conducted on sunny days with $<60 \%$ cloud cover and wind speeds of $<20 \mathrm{~km} / \mathrm{h}$. No surveys were performed during rainy or foggy periods. Binoculars $(10 \times 42)$ and a $20 \sim 60 \times$ spotting scope were used to identify the raptors sighted.

\section{Roadside point transects}

Each route consisted of 10 sample points at least $5 \mathrm{~km}$ apart (a mean distance between points of $5.57 \mathrm{~km}$ and a range of $5.00 \sim 8.49 \mathrm{~km})$. Each sample point was surveyed for $30 \mathrm{~min}$ (with a total effort/route of $5 \mathrm{~h}$ ) by one experienced observer. All raptors seen or heard were tallied within a $1-\mathrm{km}$ radius (in a single-point sampled area of $3.14 \mathrm{~km}^{2}$ and a transect sampled area of $31.4 \mathrm{~km}^{2}$ ). Before beginning each survey at a given point, distances of several structures inside the sample area (e.g., forest stands, buildings, and poles) were taken with laser rangefinder binoculars. This helped define the sample area (with a $1-\mathrm{km}$ radius) in addition to preventing the counting of raptors outside the area. In order to avoid double counting, the sampled area was divided into eight 


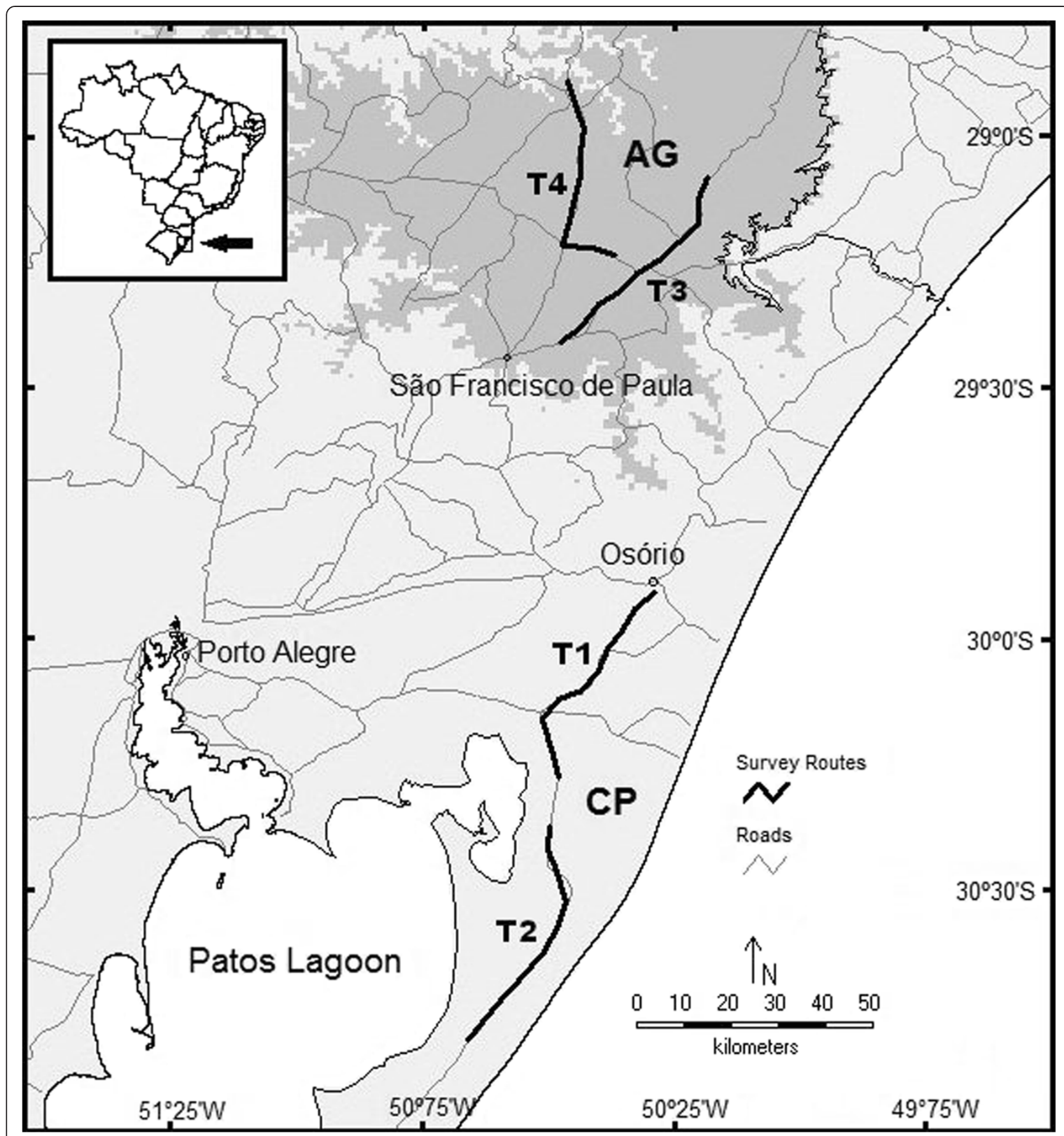

Figure 1 Study area and routes surveyed. Study sites and routes surveyed (black lines) in altitudinal grasslands (AGs) and on the coastal plain (CP) in Rio Grande do Sul, southern Brazil. Light gray areas are at elevations up to $760 \mathrm{~m}$, and dark gray areas are above $760 \mathrm{~m}$. Transect lengths: $\mathrm{T} 1=54.5 \mathrm{~km}, \mathrm{~T} 2=58.6 \mathrm{~km}, \mathrm{~T} 3=55.0 \mathrm{~km}$, and $\mathrm{T} 4=55.4 \mathrm{~km}$.

sections, and all raptors recorded were plotted on a sketch. Furthermore, the time and when possible, the behavior (e.g., hunting, perched, or soaring), gender, age, color morph, molting, and natural marks were noted to ensure that individuals were not tabulated more than once. For gregarious raptors (e.g., New World vultures), the maximum number of individuals recorded at the same time (in one or more flocks) was assumed to be the minimum number of individuals at the sample point. Surveys began about $2 \mathrm{~h}$ after local sunrise (at about 0630 hours in summer and 0715 hours in winter) and lasted for about $6.5 \mathrm{~h}$ (mean, $6.67 \mathrm{~h}$; range, $6.08 \sim 7.25 \mathrm{~h}$ ). 


\section{Roadside strip transects}

Two observers, one in the front seat and another in the back seat, and a driver (also responsible for keeping records) carried out the roadside strip transect surveys. Raptors were counted from a four-door vehicle driven at a low speed $(10 \sim 40 \mathrm{~km} / \mathrm{h})$. Only a few cases required the team to stop the vehicle to confirm an identification; however, no other raptors were recorded during such stops. All raptors seen or heard within $1 \mathrm{~km}$ on both sides of the road were tallied (with a mean transect sampled area of $111.75 \mathrm{~km}^{2}$ ). Behavior, gender, age, color morph, molting, and natural marks were recorded (or at least taken into account), on every possible occasion, to avoid double counting. Two routes were surveyed each day, beginning, respectively, around 3 and $6 \mathrm{~h}$ after local sunrise and ending about $2 \mathrm{~h}$ (mean, $2.25 \mathrm{~h}$; range, $2.02 \sim 2.47 \mathrm{~h}$ ) later.

\section{Statistical analyses}

We performed analysis of variance (ANOVA/MANOVA) tests with permutations to compare the species richness and abundance of raptors detected on transects to evaluate differences among areas and between survey methods. This method uses a sum-of-squares test $(\mathrm{Qb})$ based on the dissimilarity between groups, including a test of multiple contrasts (Pillar and Orlóci 1996). Before the analysis, species richness was rarefied by the number of individuals recorded (performed using the PAST statistical package; Hammer et al. 2001), and the abundance recorded on each transect (ordinary abundance being the number of contacts per transect) was standardized to the sampled area and survey effort (standardized abundance $=$ individuals $\cdot\left[10 \mathrm{~km}^{2}\right]^{-1} \cdot \mathrm{h}^{-1}$ ), with area indicating the sampled area and time indicating the survey effort. We created a matrix of Euclidian distances to species richness and a matrix of chord distances to the abundance as dissimilarity matrixes and ran 9,999 random permutations to calculate the sum of squares and probability $p\left(\mathrm{Qb}_{0} \geq \mathrm{Qb}_{\mathrm{A}}\right)$. The probability $p$ is a proportion of the sum of squares calculated in each iteration $\left(\mathrm{Qb}_{0}\right)$ that is greater than or equal to the sum of squares calculated for the sample $\left(\mathrm{Qb}_{\mathrm{A}}\right)$. We found differences in raptor abundances among areas $(p \leq 0.05)$, so the test between methods was performed as a block design, with permutations restricted to each sample. Analyses were performed using the MULTIV software (Pillar 2006). Data are presented as the mean \pm standard deviation.

\section{Results and discussion Results}

In total, 1,890 observations of raptors (118.13 individuals (ind.)/transect) of 18 species were recorded during the surveys (Table 1). Species richness was similar for the altitudinal grasslands (16 species) and coastal plain (14 species) $(p=0.26)$; it also did not differ between survey methods $(p=0.25$; Table 1$)$. Seventeen species were recorded during roadside point transect surveys, five of which were only recorded with this method. During the roadside strip transect surveys, 13 species were recorded, all but one of which were also recorded during roadside point transect surveys (Table 1). The Lesser Yellow-headed Vulture and Snail Kite were recorded only on the coastal plain, whereas the King Vulture, Crowned Eagle, Black-chested Buzzard-eagle, and Shorttailed Hawk were recorded only on altitudinal grasslands (Table 1).

There was a higher abundance of raptors on the altitudinal grasslands $(299.25 \pm 48.91$ ind./transect $)$ than on the coastal plain $(86.63 \pm 44.04$ ind./transect $)(p<0.001)$. The Black Vulture was the most abundant species, accounting for $42.2 \%$ of raptors recorded. Its abundance was sixfold higher in altitudinal grasslands than in the coastal plain; however, altitudinal grasslands still had greater abundance if Black Vultures were removed from the analysis $(p<0.001)$. In addition to the Black Vulture, the most abundant species on altitudinal grasslands were caracaras (Caracara plancus, Milvago spp.), the American Kestrel, and Turkey Vulture (Table 1). On the coastal plain, the Southern Caracara, Savanna, American Kestrel, and Snail Kite were the dominant species (Table 1).

The abundance recorded with the roadside point transect method $\left(9.38 \mathrm{ind} \cdot\left[10 \mathrm{~km}^{2}\right]^{-1} \cdot \mathrm{h}^{-1}\right)$ was around 2.5 times higher than that recorded with the roadside strip transect method (3.55 ind $\left.\cdot\left[10 \mathrm{~km}^{2}\right]^{-1} \cdot \mathrm{h}^{-1}\right)(p=0.05)$ (Table 1). All species showed higher abundances when surveyed by roadside point transects than roadside strip transects (Table 1). Results for the ordinary abundance (number of individuals/transect) were similar in both cases. All but four species (Roadside Hawk, Short-tailed Hawk, Yellowheaded Caracara, and American Kestrel) had higher ordinary abundances recorded on roadside point transects (Table 1).

\section{Discussion}

\section{Richness and abundance of raptors}

The coastal plain and altitudinal grasslands supported quite different raptor assemblages. Although the regions exhibited similar richness values, most species were more abundant on the altitudinal grasslands. Relief, habitat availability, anthropogenic occupation, and the level of disturbance differ between these regions, and species-habitat relationships could explain differences in assemblage compositions (Zilio et al. 2012). On altitudinal grasslands, patches of natural grassland are surrounded by forest remnants, resulting in a mosaic-like landscape. Hence, the assemblage included both forest raptors and large grassland raptors (Petersen et al. 2011; Zilio et al. 2012). Half of the 


\begin{tabular}{|c|c|c|c|c|c|c|}
\hline \multirow[t]{2}{*}{ Species } & \multicolumn{2}{|c|}{ Roadside point transect } & \multicolumn{2}{|c|}{ Roadside strip transect } & \multicolumn{2}{|c|}{ Ordinary abundance } \\
\hline & $\begin{array}{l}\text { Ordinary } \\
\text { abundance }\end{array}$ & $\begin{array}{l}\text { Standardized } \\
\text { abundance }\end{array}$ & $\begin{array}{l}\text { Ordinary } \\
\text { abundance }\end{array}$ & $\begin{array}{l}\text { Standardized } \\
\text { abundance }\end{array}$ & $\begin{array}{l}\text { Coastal } \\
\text { plain }\end{array}$ & $\begin{array}{l}\text { Altitudinal } \\
\text { grasslands }\end{array}$ \\
\hline Cathartidae & $77 \pm 51.01$ & $4.90 \pm 3.04$ & $35 \pm 25.11$ & $1.41 \pm 0.96$ & $25.13 \pm 19.87$ & $173.75 \pm 41.07$ \\
\hline Turkey Vulture (Cathartes aura) & $8.38 \pm 8.48$ & $0.53 \pm 0.51$ & $3.50 \pm 4.87$ & $0.14 \pm 0.18$ & $0.75 \pm 2.12$ & $22.25 \pm 6.58$ \\
\hline $\begin{array}{l}\text { Lesser Yellow-headed Vulture (Cathartes } \\
\text { burrovianus) }\end{array}$ & $0.13 \pm 0.35$ & $<0.01 \pm 0.02$ & - & - & $0.13 \pm 0.35$ & - \\
\hline Black Vulture (Coragyps atratus) & $68.38 \pm 45.12$ & $4.35 \pm 2.67$ & $31.50 \pm 23.11$ & $1.27 \pm 0.88$ & $24.25 \pm 18.67$ & $151.25 \pm 38.60$ \\
\hline King Vulture (Sarcoramphus papa) & $0.13 \pm 0.35$ & $<0.01 \pm 0.02$ & - & - & - & $0.25 \pm 0.35$ \\
\hline Accipitridae & $23.00 \pm 24.15$ & $1.46 \pm 1.44$ & $15.13 \pm 10.37$ & $0.61 \pm 0.36$ & $29 \pm 21.57$ & $18.25 \pm 5.96$ \\
\hline Snail Kite (Rostrhamus sociabilis) & $6.38 \pm 11.81$ & $0.41 \pm 0.70$ & $3.00 \pm 6.7$ & $0.11 \pm 0.22$ & $9.38 \pm 11.85$ & - \\
\hline Long-winged Harrier (Circus buffoni) & $0.88 \pm 1.13$ & $0.06 \pm 0.07$ & $0.75 \pm 0,71$ & $0.03 \pm 0.03$ & $1.38 \pm 0.92$ & $0.50 \pm 0.46$ \\
\hline Savanna Hawk (Buteogallus meridionalis) & $7.75 \pm 8.17$ & $0.49 \pm 0.49$ & $4.38 \pm 3.11$ & $0.18 \pm 0.13$ & $9.75 \pm 7.00$ & $4.75 \pm 1.69$ \\
\hline $\begin{array}{l}\text { Great Black Hawk (Buteogallus } \\
\text { urubitinga) }\end{array}$ & $0.38 \pm 1.06$ & $0.02 \pm 0.06$ & $0.25 \pm 0.46$ & $0.01 \pm 0.02$ & $0.38 \pm 1.06$ & $0.50 \pm 0.46$ \\
\hline Crowned Eagle (Buteogallus coronatus) & $0.13 \pm 0.35$ & $<0.01 \pm 0.02$ & - & - & - & $0.25 \pm 0.35$ \\
\hline Roadside Hawk (Rupornis magnirostris) & $5.88 \pm 5.38$ & $0.37 \pm 0.31$ & $6.50 \pm 5.13$ & $0.27 \pm 0.20$ & $8.00 \pm 5.86$ & $8.75 \pm 3.70$ \\
\hline $\begin{array}{l}\text { White-tailed Hawk (Geranoaetus } \\
\text { albicaudatus) }\end{array}$ & $0.75 \pm 1.75$ & $0.01 \pm 0.10$ & $0.13 \pm 0.35$ & $<0.01 \pm 0.01$ & $0.13 \pm 0.35$ & $1.50 \pm 1.75$ \\
\hline $\begin{array}{l}\text { Black-chested Buzzard-eagle } \\
\text { (Geranoaetus melanoleucus) }\end{array}$ & $0.88 \pm 1.75$ & $0.06 \pm 0.09$ & - & - & - & $1.75 \pm 1.45$ \\
\hline Short-tailed Hawk (Buteo brachyurus) & - & - & $0.13 \pm 0.35$ & $<0.01 \pm 0.01$ & - & $0.25 \pm 0.35$ \\
\hline Falconidae & $47.38 \pm 14.59$ & $3.02 \pm 0.87$ & $37.13 \pm 16.23$ & $1.47 \pm 0.53$ & $32.38 \pm 9.62$ & $104 \pm 14.86$ \\
\hline Southern Caracara (Caracara plancus) & $17.63 \pm 8.00$ & $1.12 \pm 0.48$ & $13.00 \pm 2.98$ & $0.53 \pm 0.13$ & $16.88 \pm 7.47$ & $27.5 \pm 4.86$ \\
\hline $\begin{array}{l}\text { Yellow-headed Caracara (Milvago } \\
\text { chimachima) }\end{array}$ & $3.13 \pm 3.36$ & $0.20 \pm 0.20$ & $4.50 \pm 5.48$ & $0.17 \pm 0.19$ & $1.25 \pm 0.71$ & $12.75 \pm 5.18$ \\
\hline Chimango Caracara (Milvago chimango) & $15.38 \pm 11.78$ & $0.98 \pm 0.70$ & $5.75 \pm 6.32$ & $0.22 \pm 0.23$ & $4.75 \pm 3.85$ & $32.75 \pm 11.82$ \\
\hline American Kestrel (Falco sparverius) & $10.88 \pm 4.82$ & $0.69 \pm 0.29$ & $13.88 \pm 9.52$ & $0.54 \pm 0.22$ & $9.38 \pm 4.07$ & $30.75 \pm 9.05$ \\
\hline Aplomado Falcon (Falco femoralis) & $0.38 \pm 0.74$ & $0.02 \pm 0.04$ & - & - & $0.13 \pm 0.35$ & $0.50 \pm 0.71$ \\
\hline Not identified to species & - & - & $1.63 \pm 2.07$ & $0.06 \pm 0.08$ & $0.13 \pm 0.35$ & $3.00 \pm 2.13$ \\
\hline Total & $147.38 \pm 60.97$ & $9.38 \pm 3.63$ & $88.88 \pm 30.50$ & $3.55 \pm 1.08$ & $86.63 \pm 44.04$ & $299.25 \pm 48.91$ \\
\hline
\end{tabular}

They were surveyed using roadside point transects and roadside strip transects along four routes in two regions of southern Brazil in 2009 and 2010 . Taxonomy follows Remsen et al. (2012).

species recorded only on the altitudinal grasslands, the King Vulture and Short-tailed Hawk, are typically associated with forests, while the other two, the Crowned Eagle and Black-chested Buzzard-eagle, are characterized as open-woodland and grassland species (Ferguson-Lees and Christie 2001). In contrast, raptors related to wet habitats (e.g., marshes, swamps, and rice fields) were more common on the coastal plain (Albuquerque et al. 1986; Zilio et al. 2012). For example, the Lesser Yellow-headed Vulture and Snail Kite inhabit wet savannahs, marshes, and rice fields (Belton 1984; Ferguson-Lees and Christie 2001). These two species were only recorded on the coastal plain.

The assemblage on the coastal plain was characterized by species associated with wet habitats and that are also tolerant of human disturbance. The most abundant species, the Black Vulture and Southern Caracara, are both regularly found in urban and agricultural areas (FergusonLees and Christie 2001; Alencar-Carvalho and Marini 2007), although the latter is also found in natural grasslands (Filloy and Bellocq 2007; Pedrana et al. 2008). The American Kestrel and Roadside Hawk are abundant in Rio Grande do Sul (Belton 1984). They are food and habitat generalists (Ferguson-Lees and Christie 2001), show a high tolerance to human disturbance, and are even found inside big cities (Belton 1984; Scherer et al. 2005). The Snail Kite and Savanna Hawk are common in coastal areas of southern Brazil and Uruguay (Belton 1984; Albuquerque et al. 1986; Arballo and Cravino 1999; Zilio et al. 2012). These species were abundant on the coastal plain, surely 
favored due to the availability of marshes and rice fields in the region. The Long-winged Harrier had a similar pattern of distribution, being more abundant on the coastal plain than on altitudinal grasslands, agreeing with Albuquerque et al. (1986) who found high abundances further to the south. The occurrence of Long-winged Harriers was positively associated with marshes (Pedrana et al. 2008), a common habitat type on the coastal plain, but a habitat type less frequently encountered in altitudinal grasslands (F Zilio personal observation).

The assemblage on altitudinal grasslands was similar to that found by Petersen et al. (2011). Black Vultures, caracaras, and American Kestrels were the most abundant species, while the Accipitridae (hawks, harriers, kites, and eagles) showed lower abundances. The dominance of one or two vulture species, and the Southern and Chimango caracaras, is a common pattern of abundance in many raptor assemblages in the grasslands of southern South America (Donázar et al. 1993; Bellati 2000; Carrete et al. 2009). The Accipitridae is usually not abundant, with a couple of profuse, generalist species along with some uncommon or rare ones.

Altitudinal grasslands are important for the conservation of raptors. Three of the species recorded only in this region, the King Vulture, Black-chested Buzzardeagle, and Crowned Eagle, are threatened in the Rio Grande do Sul (Marques et al. 2002), whereas the last is globally endangered (IUCN 2012). Apparently, the King Vulture has two separate populations in Rio Grande do Sul (Bencke et al. 2003). One is restricted to large forest remnants found on the northeastern plateau (Campos de Cima da Serra and Serra Geral), while the other is in Turvo State Park located in the northwestern part of the state (Bencke et al. 2003). The Black-chested Buzzardeagle is uncommon, although largely dispersed, in Rio Grande do Sul (Bencke et al. 2003). Most records of this species in the state are from western and southwestern regions, where it is more common, and on the northeastern plateau (Bencke et al. 2003; Zilio et al. 2012). The Crowned Eagle has only been recorded on the northeastern plateau in the Rio Grande do Sul (Bencke et al. 2003). Despite the fact that it hunts in open areas, this eagle needs large trees to support its nest (Ferguson-Lees and Christie 2001), a factor that probably constrains its potential distribution in Rio Grande do Sul. Direct persecution and habitat degradation have contributed to population declines of this species (Ferguson-Lees and Christie 2001; BirdLife International 2012).

\section{Roadside transect methods}

Roadside transect methods are the most commonly employed techniques for surveying raptors in open grasslands around the world (Albuquerque et al. 1986;
Ellis et al. 1990; Donázar et al. 1993; Lederle et al. 2000; Boano and Toffoli 2002; Jensen et al. 2005; Thiollay 2006). Our results support the efficacy of such methods to gather data on raptor abundances and distributions. A substantial proportion of the expected richness was recorded, $73 \%$ for altitudinal grasslands and $87 \%$ for the coastal plain (based on Albuquerque et al. 1986; Belton 1984; Teixeira and Teixeira 2008; Petersen et al. 2011). The difference in the proportions recorded is probably due to the number of forest raptors in the altitudinal grasslands (e.g., Spizaetus spp. and Accipiter spp.), which are more difficult to detect than grassland species.

Our results suggest that roadside point transects are better than roadside strip transects, at least for evaluating the abundance of raptors. Compared to Petersen et al. (2011), who surveyed one of the same routes (RS020 between São Francisco de Paula and Cambará do Sul, Route T3 in Figure 1), we found a similar richness (16 vs. 13). It was an expected result given that our analyses showed no significant differences between the two methods when assessing richness. However, during roadside point transects, we recorded about twice as many raptors (434 observations) as Petersen et al. (2011; 243 observations). Despite recording almost the same number of raptors (230 observations) as Petersen et al. (2011) during roadside strip transects, the conversion of the abundance to the number of observations per kilometer generated a large difference (2.09 ind./km vs. 0.12 ind. $/ \mathrm{km}$ ). Unfortunately, such results are difficult to interpret because Petersen et al. (2011) provided no information on car speed, transect width, time of day, or weather conditions, features that could have biased the results (Fuller and Mosher 1987).

The efficiency of roadside point transects for estimating abundance could be related to better stationary scanning of the sample area for raptors rather than observers constantly moving along the route. The time spent scanning each unit of area (e.g., a hectare) in roadside strip transects tends to be shorter than when conducting roadside point transects, reducing the probability of detecting inconspicuous raptors. However, roadside point transects tend to increase the probability of individual detection, particularly of raptors perched in less exposed sites (e.g., in a tree with dense foliage, on a fence, or on the ground), where the sighting of raptors might be more difficult (Diesel 1984). Increasing the duration of the survey may compensate for differences in the probability of detection among species with different foraging behaviors. Most species, both those that usually soar and have active flight-foraging behaviors (e.g., vultures and the Black-chested Buzzard-eagle) and those that forage on the ground or from a perch (e.g., Savanna Hawk and Southern Caracara), were more abundant in the roadside point 
transects than strip transects, suggesting that the former is less sensitive to species behavior.

Roadside point transects may be better for detecting rare and uncommon species, such as the Lesser Yellowheaded Vulture, Aplomado Falcon, King Vulture, Crowned Eagle, and Black-chested Buzzard-eagle, which are uncommon, or even threatened (the latter three), in Rio Grande do Sul (Belton 1984; Marques et al. 2002); these species were only recorded using the roadside point transect method. For example, the Black-chested Buzzardeagle, a large soaring species, was recorded six times, and it was neither recorded during roadside strip transects nor by Petersen et al. (2011), supporting our hypothesis that roadside point transects are better than roadside strip transects. In addition, the differences we found between methods were barely supported by statistical significance, and further efforts to compare these methods are needed before claiming superiority of one over the other.

The choice of method must take into account factors such as the budget, time, staff availability, study area, certainly the hypothesis to be evaluated, and the goals of the study. Some advantages and disadvantages of roadside point counts and roadside strip transects are outlined:

1. Habitat effects. Habitat availability can affect distributions of species along roads (Austin et al. 2000; Meunier et al. 2000); hence, roadside surveys could bias estimations of population sizes and complicate assessments of species compositions (Hanowsky and Niemi 1995; Keller and Fuller 1995). An advantage of roadside point transects is that locations of point counts can be selected along roads according to habitat availability or restricted to specific selected habitats (e.g., marshes or crop fields), while roadside strip transect surveys encompass all habitats along a route. Surveying each habitat proportionally to its availability could reduce bias due to differences in the probability of detection of distinct habitat types (Millsap and LeFranc 1988) or due to habitat preferences of individual species (Hanowsky and Niemi 1995; Keller and Fuller 1995).

2. Time and length of the survey. The time of day may bias raptor roadside surveys. Species activities supposedly change through the day, as reflected in species detectability. Hence, surveys could underestimate species abundances and richness depending on the time of day that the survey is conducted (Bunn et al. 1995; Vergara 2010). Roadside point transects take longer than roadside strip transects. Carrying out roadside point transect surveys that take nearly the entire day could bias abundance estimates of species that change activities during the day. In contrast, roadside strip transects can be conducted only during specific periods of the day, when raptors are expected to be more readily detectable (e.g., in late mornings when thermals and updrafts enable soaring flight; Fuller and Mosher 1987; Vergara 2010). However, changes in species abundance can be found even in a few hours; hence, the results from short roadside surveys (e.g., $<2$ h) may have a greater probability of being affected by the time of day (Vergara 2010). Because raptors are less frequently detected when perched than flying in open habitats (Diesel 1984), we think that it is more appropriate to use techniques that increase detection of perched raptors, as the roadside point transect method seems to do, rather than those focused on flying ones. This could minimize time-ofday biases in estimating abundances of species when they are less active (e.g., resting).

3. Double counting. As birds frequently move, the longer the duration of the point count, the higher the probability is of double counting a bird. This can be a problem with roadside point transect surveys because much more time is spent surveying the same location than in the case on roadside strip transects. However, a couple of simple rules can be applied to reduce the probability of double counting. First, a minimum number of individual birds can be used as an abundance index per sample point, which is the maximum number of birds recorded at once. Second, one can reduce the probability of double counting by plotting all records in a sketch.

Raptors are target species of several conservation programs (see examples at the Peregrine Fund website, www. peregrinefund.org). Many of these species that are globally threatened (IUCN 2012) have been used as flagship or umbrella species and are useful indicators of biodiversity (Sergio et al. 2006, 2008). Given their ecological importance, along with conservation issues, results from biased surveys may have undesirable consequences beyond the simple evaluation of raptor assemblages. Our data suggest that roadside point transects are better than roadside strip transects for recording abundances of raptors as well as rare and threatened species in open landscapes. However, studies that compare roadside point transects with other methods, especially roadside strip transects, in other open landscapes around the world are required to assess the generality of our findings. The effects of time of day, habitat features, and other aspects that could affect species detection also need further investigations to assess potential biases. Biased results have limited applications (Andersen 2007). Given that many sources of bias from roadside surveys are difficult or even impossible to avoid, we recommend that the ones that can be controlled (e.g., the time of the survey, sampled area, and number of observers) be standardized to enhance comparability of survey results. 


\section{Conclusions}

The raptor assemblages of the coastal plain and altitudinal grasslands are quite different. Despite these regions exhibiting similar species richness, they differed in species abundances. The regions differ in landscape features (e.g., relief and habitat availability) and the level of disturbance, and species-habitat relationships could explain differences in assemblage compositions. As regards the methods, despite the choice of survey method that depended on the objectives of the study, our results favor the use of point transects rather than strip transects to survey raptors in open landscapes. Roadside point transects may reduce bias due to differences in species detection caused by habitat features and in abundance estimates resulting from survey habitat being disproportional to their availability. Point counts may enhance the quality of the search for raptors in a surveyed area, increasing the detection probability. However, studies that compare roadside point transects with other methods, in other open landscapes around the world, are required to assess the generality of our findings.

\section{Competing interests}

The authors declare that they have no competing interests.

\section{Authors' contributions}

FZ participated in the design and coordination of the study, analyzed the data, and drafting the manuscript. $F Z, A B, C O S$, and $A M L$ carried out the raptor surveys. $A M L$ analyzed the data. $L V$ and $M B M$ participated in the design of the study and its coordination. FZ, $A B, A M L, C O S, L V$, and MBM finalized the manuscript. All authors read and approved the final manuscript.

\section{Acknowledgements}

We thank Eduardo Chiarani for his field assistance when conducting surveys. The Peregrine Fund Library, Marcus Canuto, and Rafael Tosi helped with the bibliography. Carla S. Fontana, Helena P. Romanowsky, Ignácio B. Moreno, José H. Sarasola, Beatriz Arroyo, and anonymous referees provided valuable comments that improved the manuscript. We appreciate the improvements in English usage made by Christina Riehl through the editorial assistance program of the Association of Field Ornithologists. Leonardo Zilio, Rafaela Barbosa, and Tiago Cattani also provided help with English in earlier drafts. During this study, F. Zilio held doctoral fellowships from the Capes.

\section{Author details \\ ${ }^{1}$ Programa de pós-graduação em Biologia Animal, Departamento de Zoologia, Universidade Federal do Rio Grande do Sul, Av. Bento Gonçalves, 9500, Porto Alegre CEP 91501-970 Rio Grande do Sul, Brazil. ${ }^{2}$ Curso de Ciência Biológicas, Departamento de Ecologia, Universidade Federal do Rio Grande do Sul, Av. Bento Gonçalves, 9500, Porto Alegre CEP 91501-970, Rio Grande do Sul, Brazil. ${ }^{3}$ Programa de pós-graduação em Ecologia, Departamento de Ecologia, Universidade Federal do Rio Grande do Sul, Av. Bento Gonçalves, 9500, Porto Alegre CEP 91501-970, Rio Grande do Sul, Brazil. ${ }^{4}$ Curso de Ciência Biológicas, Departamento de Zoologia, Universidade Federal do Rio Grande do Sul, Porto Alegre, RS, Brazil. ${ }^{5}$ Laboratório de Herpetologia, Departamento de Zoologia, Universidade Federal do Rio Grande do Sul, Av. Bento Gonçalves, 9500, Porto Alegre CEP 91501-970 Rio Grande do Sul, Brazil.}

Received: 31 January 2013 Accepted: 10 July 2013 Published: 4 October 2013

\section{References}

Albuquerque JLB, Ghizoni-Jr IR, Silva ES, Trainini G, Franz I, Barcellos A, Hassdenteufel CB, Arend FL, Martins-Ferreira C (2006) Crowned Solitary-Eagle
(Harpyhaliaetus coronatus) and Crested-Eagle (Morphnus guianenis) in Santa Catarina and Rio Grande do Sul: priorities and challenges to their conservation. Rev Brasil Ornitol 14:411-415 (in Portuguese with English summary)

Albuquerque JLB, Witech AJ, Aldous AM (1986) A roadside count of diurnal raptors in Rio Grande do Sul, Brazil. Birds Prey Bull 3:82-87

Alencar-Carvalho CE, Marini MA (2007) Distribution patterns of diurnal raptors in open and forested habitats in south-eastern Brazil and the effects of urbanization. Bird Conserv Int 17:367-380

Alldredge MW, Pacifici K, Simons TR, Pollock KH (2008) A novel field evaluation of the effectiveness of distance and independent observer sampling to estimate aural avian detection probabilities. J Appl Ecol 45:1349-1356

Amaral FR, Sheldon FH, Gamauf A, Haring E, Riesing M, Silveira LF, Wajntal A (2009) Patterns and processes of diversification in a widespread and ecologically diverse avian group, the buteonine hawks (Aves, Accipitridae). Mol Phylogen Evol 53:703-715

Andersen DE (2007) Survey techniques. In: Bird DM, Bildstein KL (eds) Raptor research and management techniques. Hancock House Publisher, Blaine, WA, pp 89-100

Arballo E, Cravino J (1999) Aves del Uruguay, Manual ornitológico vol. 1. Editorial Hemisferio Sur, Montevideo (in Spanish)

Austin JE, Sklebar HT, Gutensperger GR, Buhl TK (2000) Effects of roadside transect width on waterfowl and wetland estimates. Wetlands 20:660-670

Azevedo MAG, Machado DA, Albuquerque JBL (2003) Birds of prey in the Santa Catarina Island, SC: composition, frequency of occurrence, habitat use and conservation. Ararajuba 11:75-81 (in Portuguese with English summary)

Barcellos A, Accordi IA (2006) New records of the Crowned Eagle, Harpyhaliaetus coronatus, in the state of Rio Grande do Sul, southern Brazil. Rev Brasil Ornitol 14:345-349

Bellati J (2000) Comportamiento y abundancia relativa de rapaces de la Patagonia Extraandina Argentina. Neotrop Ornitol 11:207-222

Belton W (1984) Birds of Rio Grande do Sul, Brazil. Part 1. Rheidae through Furnariidae. Bull Am Mus Nat Hist 178:369-636

Bencke GA, Fontana CS, Dias RA, Maurício GN, Mähler JFK Jr (2003) Aves. In: Fontana CS, Bencke GA, Reis RE (eds) Livro vermelho da fauna ameaçada de extinção no Rio Grande do Sul. EDIPUCRS, Porto Alegre, pp 189-477 (in Portuguese)

Bencke GA, Mauricio GN, Develey PF, Goerck JM (2006) Áreas importantes para a conservção de aves no Brasil, Parte I - estados de domínio de Mata Atlântica, SAVE Brasil, São Paulo., in Portuguese and English

Bierregaard RO Jr (1995) The biology and conservation status of Central and South American Falconiformes: a survey of current knowledge. Bird Conserv Int 5:325-340

Bierregaard RO Jr (1998) Conservation status of birds of prey in the South America tropics. J Raptor Res 32:19-27

BirdLife International (2012) Harpyhaliaetus coronatus. In: IUCN 2012: IUCN red list of threatened species, version 2. http://www.iucnredlist.org. Accessed 8 Jan 2013

Boano G, Toffoli R (2002) A line transect survey of wintering raptors in the western Po Plain of northern Italy. J Raptor Res 36:128-135

Buckland ST, Marsden SJ, Green RE (2008) Estimating bird abundance: making methods work. Bird Conserv Int 18:91-108

Bunn AG, Klein W, Bildstein KL (1995) Time-of-day effects on the numbers and behaviour of non-breeding raptors seen on roadside surveys in eastern Pennsylvania. J Field Ornithol 66:544-552

Cabanne GS, Seipke SH (2005) Migration of the Rufous-thighed Kite (Harpagus diodon) in southeastern Brazil. Ornitol Neotrop 16:547-549

Carrete M, Tella JL, Blanco G, Bertelloti M (2009) Effects of habitat degradation on the abundance, richness and diversity of raptors across Neotropical biomes. Biol Conserv 142:2002-2011

CBRO (2011) Brazilian committee of ornithological records, 10th edn, Brazilian bird species list. http://www.cbro.org.br. Accessed 25 Oct 2012

Diesel DA (1984) Evaluation of the road survey technique in determining flight activity of Red-tailed Hawks. Wilson Bull 96:315-318

Donázar JA, Ceballos O, Travaini A, Hiraldo F (1993) Roadside raptor surveys in the Argentinean Patagonia. J Raptor Res 27:106-110

Ellis DH, Glinski RL, Smith DG (1990) Raptor road surveys in South America. J Raptor Res 24:98-106

Ferguson-Lees J, Christie DA (2001) Raptors of the world. Houghton Mifflin, New York

Filloy J, Bellocq MI (2007) Respuesta de lasaves rapaces al uso de la tierra: un enfoque regional. Hornero 22:131-140 (in Spanish with English summary) 
Fuller MR, Mosher JA (1987) Raptor survey techniques. In: GironPedlenton B, Millsap BA, Cline KW, Bird DM (eds) Raptor management techniques manual. National Wildlife Federation, Washington DC, pp 37-65

Hammer O, Harper DAT, Ryan PD (2001) PAST: paleontological statistical software package for education and data analysis. Palaeontol Electron 4:9, available at http://folk.uio.no/ohammer/past

Hanowsky JM, Niemi GJ (1995) A comparison of on- and off-road bird counts: do you need to go off road to count birds accurately? J Field Ornithol 66:469-483

IUCN (2012) IUCN Red list of threatened species, version 2. http://www.iucnredlist.org. Accessed 25 Oct 2012

Jensen WJ, Gregory MS, Baldassarre GA, Vilella FJ, Bildstein KL (2005) Raptor abundance and distribution in the Llanos wetlands of Venezuela. J Raptor Res 39:417-428

Joenck CM (2006) Records of Spizaetus tyrannus (Accipitridae) in the Centro de Pesquisas e Conservação da Natureza Pró-Mata (CPCN Pró-Mata) in northeast of the Rio Grande do Sul. Rev Brasil Ornitol 14:427-428 (in Portuguese with English summary)

Joenck CM, Azevedo MAG (2006) New records of Leptodon cayanensis (Accipitridae) in the states of Rio Grande do Sul and Santa Catarina, Brazil. Rev Brasil Ornitol 14:423-425 (in Portuguese with English summary)

Keller CME, Fuller MR (1995) Comparison of birds detected from roadside and off-road point counts in the Shenandoah National Park. In: Ralph CJ, Sauer $J R$, Droege $S$ (eds) Monitoring bird populations by point counts. USDA Forest Service General Technical Report PSW-GTR-149, Albany, CA, pp 111-115

Krügel MM (2003) Documented record of Condrohierax uncinatus (Temmink, 1822) (Faloniformes: Accipitridae) in Rio Grande do Sul. Ararajuba 11:83-84 (in Portuguese with English summary)

Lederle PE, Mueller JM, Holt EA (2000) Raptor surveys in south central Nevada, 1991-95. J Raptor Res 34:133-136

Loures-Ribeiro A, Anjos L (2006) Falconiformes assemblages in a fragmented landscape of Atlantic forest in south Brazil. Braz Arch Biol Techn 49:149-162

Mañosa S, Mateos E, Pedrocchi V (2003) Abundance of soaring raptors in the Brazilian Atlantic rainforest. J Raptor Res 37:19-30

Marques AAB, Fontana CS, Vélez E, Bencke GA, Schneider M, Reis RE (2002) Lista das Espécies da Fauna Ameaçadas de Extinção no Rio Grande do Sul. FZB/ MCT-PUCRS/PANGEA, Porto Alegre (in Portuguese)

Meller DA (2011) Aves de Rapina do Parque Estadual do Turvo, Rio Grande do Sul, Brasil. Univ. Regional Integrada do alto Uruguai e das Missões (URI), Santo Ângelo (in Portuguese with English summary)

Meller DA, Bencke GA (2012) First record of the Broad-winged Hawk Buteo platypterus in southern Brazil, with a compilation of published records for the country. Rev Bras Ornitol 20:75-80

Mendonça-Lima A, Zilio F, Joenck CM, Barcellos AS (2006) New records of the Ornate Hawk-Eagle Spizaetus ornatus (Accipitridae) in southern Brazil. Rev Brasil Ornitol 14:279-282 (in Portuguese with English summary)

Meunier FD, Verheyden C, Jouventin P (2000) Use of roadsides by diurnal raptors in agricultural landscapes. Biol Conserv 92:291-298

Millsap BA, LeFranc MN Jr (1988) Road transect counts for raptors: how reliable are they? J Raptor Res 22:8-16

Overbeck GE, Müller SC, Fidelis A, Pfadenhauer J, Pillar VD, Blanco CC, Boldrini II, Both R, Forneck ED (2007) Brazil's neglected biome: the south Brazilian campos. Perspect Plant Ecol Evol Systemat 9:101-106

Pedrana J, Isacch JP, Bó MS (2008) Habitat relationships of diurnal raptors at local and landscapes scales in southern temperate grasslands of Argentina. Emu 108:301-310

Petersen ES, Petry MV, Krüger-Garcia L (2011) Use of different habitat by raptors in southern Brazil. Rev Brasil Ornitol 19:376-384 (in Portuguese with English summary)

Pillar VD (2006) MULTIV multivariate exploratory analysis, randomization testing and bootstrap resampling, User's guide (vers. 2.4). Universidade Federal do Rio Grande do Sul Porto Alegre, http://ecoqua.ecologia.ufrgs.br/ecoqua/ MULTIV.html. Accessed 12 May 2011

Pillar VD, Orlóci L (1996) On randomization testing in vegetation science: multifactor comparisons of relevé groups. J Veg Sci 7:585-592

Ralph CJ (1981) Terminology used in estimating numbers of terrestrial birds. Stud Avian Biol 6:577-578

Ralph CJ, Scott JM (1981) Estimating numbers of terrestrial birds. In: Studies in Avian Biology 6. Allen Press and Cooper Ornithological Society, Lawrence

Remsen JV Jr, Cadena CD, Jaramillo A, Nores M, Pacheco JF, Pérez-Emán J, Robbins MB, Stiles FG, Stotz DF, Zimmer KJ (2012) A classification of the bird species of South America (21 Sept. 2012 version), American Ornithologists'
Union. http://www.museum.lsu.edu/ Remsen/SACCBaseline.html. Accessed 21 Sept 2012

Rosenstock SS, Anderson DR, Giesen KM, Leukering T, Carter MF (2002) Landbird counting techniques: current practices and an alternative. Auk 110:46-53

Salvador-Jr LF, Silva FA (2009) Diurnal raptors in a fragmented Atlantic forest landscape in the upper Doce River, Minas Gerais, Brazil. Bol Mus Biol Mello Leitão 25:53-65 (in Portuguese with English summary)

Scheibler DR (2007) Food partitioning between breeding White-tailed Kites (Elanus leucurus; Aves; Accipitridae) and Barn Owls (Tyto alba; Aves; Tytonidae) in southern Brazil. Braz J Biol 67:65-71

Scherer A, Scherer SB, Bugoni L, Mohr LV, Efe MA, Hartz SM (2005) Estrutura trófica da Avifauna em oito parques da cidade de Porto Alegre, Rio Grande do Sul, Brasil. Ornithologia 1:25-32 (in Portuguese with English summary)

Sergio F, Newton I, Marchesi L, Pedrini P (2006) Ecologically justified charisma: preservation of top predators delivers biodiversity conservation. J Appl Ecol 43:1049-1055

Sergio F, Caro T, Brown D, Clucas B, Hunter J, Ketchum J, McHugh K, Hiraldo F (2008) Top predators as conservation tools: ecological rationale, assumptions, and efficacy. Annu Rev Ecol Evol Systemat 39:1-19

Teixeira EC, Teixeira EC (2008) New records of Falconiformes in the Lagoa do Peixe National Park, RS - Brazil. Biodivers Pampeana 6:14-18 (in Portuguese with English summary)

Thiollay J-M (2006) The decline of raptors in West Africa: long-term assessment and the role of protected areas. Ibis 148:240-254

Thompson WL (2002) Towards reliable birds surveys: accounting for individuals present but not detected. Auk 119:18-25

Tomazelli LJ, Dillenburg SR, Wilwock JA (2000) Late quaternary geological history of Rio Grande do Sul coastal plain, southern Brazil. Rev Bras Geociênc 30:474-476

Vergara PM (2010) Time-of-day bias in diurnal raptor abundance and richness estimated by road surveys. Rev Catalana d'Ornitol 26:22-30

Whitacre DF, Turley CW (1990) Further comparisons of tropical raptors census techniques. In: Burnham WA, Whitacre DF, Jenny JP (eds) Maya Project: use of raptors and other fauna as environmental indicators for design, management, and monitoring of protected areas and for building local capacity for conservation in Latin America. Progress report III. The Peregrine Fund, Boise, pp 71-92

Zilio F, Mendonça-Lima A (2012) The White-rumped Hawk (Buteo leucorrhous) in southern Brazil: status, conservation and first description of the nest. Ornitol Neotrop 23:51-61

Zilio F, Verrastro L, Borges-Martins M (2012) Diversidade de aves de rapina dos campos do sudeste da América do Sul: influência do uso de solos e topografia na distribuição das espécies. In: Zilio F (ed) Composição e Diversidade de Taxocenoses de Aves de Rapina Diurnas de Paisagens abertas da Savana Uruguaia e Floresta Úmida com Araucária, PhD thesis. Programa de pós-graduação em Biologia Animal, UFRGS, Porto Alegre, Brazil, pp 47-79, in Portuguese with English summary)

doi:10.1186/1810-522X-52-27

Cite this article as: Zilio et al:: Raptor assemblages in grasslands of Southern Brazil: species richness and abundance and the influence of the survey method. Zoological Studies 2013 52:27.

\section{Submit your manuscript to a SpringerOpen ${ }^{\odot}$ journal and benefit from:}

- Convenient online submission

- Rigorous peer review

- Immediate publication on acceptance

- Open access: articles freely available online

- High visibility within the field

- Retaining the copyright to your article

Submit your next manuscript at springeropen.com 